\title{
INTEREST OF CZECH POPULATION IN WATER MANAGEMENT
}

\author{
Tereza Kniezková ${ }^{1}$
}

\begin{abstract}
This paper describes the process and results of a questionnaire survey. The research objective was to determine whether the Czech population has interest in water management. The subject to the creation of the survey was the fact that one of the main objectives of water policy of the European Union, on which water policy of the Czech Republic is based, is the need to increase public awareness of water issues and their involvement in the decision making process. The partial objective was to determine whether there is a difference in interest between those living in the countryside and those living in the city. In this paper a method of quantitative data collection - a questionnaire survey was used. The results show that people have interest in water management. There are no differences between the views of people who live in rural areas and those who live in the city. Great interest is in water supply and related development of water supply and sewerage systems.
\end{abstract}

Keywords: water management, questionnaire survey, Czech Republic.

Souhrn: Článek popisuje proces a výsledky dotazníkového šetření. Cílem výzkumu je určit, zda se české obyvatelstvo zajímá o vodní hospodářství. Motivem pro toto šetření byla skutečnost, že jedním z hlavních cílů vodní politiky Evropské unie, na níž je vodní politika České republiky založena, je potřeba zvýšit zájem veřejnosti o vodohospodářské problémy a její zapojení do rozhodovacího procesu. Vedlejším cílem bylo určení, zda existuji rozdíly v tomto zájmu mezi obyvateli venkova a města. Byla použita metoda sběru kvantitativních dat - dotazníkové šetření. Výsledky ukazují, že lidé mají zájem o vodní hospodářství. Nebyly zjištěny rozdíly mezi obyvateli venkova a města. Velký zájem je o dodávky vody a vztah mezi dodávkami vody a kanalizačními systémy.

Klíčová slova: vodní hospodářství, dotazníkové šetření, Česko.

\section{Introduction}

Water is an integral part of everyone's life; it is one of basic living conditions of our existence on this planet. Without water human civilization and all life in the world would die out.

\footnotetext{
1 Bc. Ing. Tereza Kniezková, Ústav aplikované a krajinné ekologie, Mendelova univerzita v Brně, Zemědělská 1 , 61300 Brno, Česká republika, e-mail: TKniezkova@seznam.cz
} 
Despite water importance and all the warning signals, many people around the world still do not realize that its quantity is constantly decreasing. The amount of clean drinking water enters the critical values (many countries do not have their own source of drinking water) and it is more than necessary to start global fight against this (Bates, 2008).

Water is constantly in motion, moving from one state to another, from place to place, which means that rational planning and management in the best conditions is a very complex and difficult task. Using water resources is limited in quantity and quality (Oki, Kanae, 2006). World water problems are neither homogeneous nor constant, but vary over time. Solving these problems depends not only on the availability of water but also on other factors (e.g. processes by which water is managed, competence and capacity of the managing institutions, the prevailing socio-political conditions) (Biswas, 2004). An essential step is to make individual states join in their efforts to effectively and properly manage and protect water resources. The basis for conservation and sustainable development of water resources today and in the future is an effective, efficient, environmentally sound water management in each country on the planet. Countries must work together to address issues of water because water does not respect borders. Only by working together it is possible to avert the impending catastrophe of water shortage.

Deteriorating quantity and quality of water resources greatly threatens the agricultural sector, which is the major consumer in many regions around the world. This situation may worsen competitiveness and lack of water may cause serious problems (e.g. agricultural non-sustainability) that arise from poorly planned water systems with limited sources of water that are available for multiple concurrent users. Studies suggest that it is necessary to focus on the protection of water for agriculture, increase the efficiency of agricultural water use and enhance crop yields with limited water availability (Li et al., 2011).

The hydrological network in the Czech Republic consists of approximately $76,000 \mathrm{~km}$ of watercourses. According to Decree No. 470/2001 Coll. establishing a list of significant watercourses and implementation of activities related to river basin management, as amended, significant water streams have a length of $15,536 \mathrm{~km}$. The backbone streams are those of the Elbe $(370 \mathrm{~km})$ and the Vltava $(433 \mathrm{~km})$ in Bohemia, the Morava $(272 \mathrm{~km})$ and the Thaya $(306 \mathrm{~km})$ in southern Moravia and the Odra $(135 \mathrm{~km})$ and the Opava $(131 \mathrm{~km})$ in the north of Moravia and Silesia. The total length of the rivers is over 60,000 km (Pokorný et al., 2008).

Water management based on water policy is an important field in the Czech Republic and has a long tradition and history. It is a purposeful activity that seeks to use, develop and protect water resources from harmful effects. The social division of labour allocates water management in many countries as a specialized activity. Water management deals only with waters, which may be affected by human activity (Plecháč, 1999).

The aim of this article was to describe the process and results of a questionnaire survey, which was to find out whether citizens of the Czech Republic have interest in water management. The subject to the creation of the survey was the fact that one of the main objectives of water policy of the European Union, on which water policy of the Czech Republic is based, is the need to increase public awareness of water issues and their involvement in the decision making process. All changes for the better have to start from zero and foundations of state and their management are formed by citizens. It should be realized that indifference of an individual leads to indifference of a society.

Water shortage and other problems associated with it are problems of all of us, so we should not turn back, but try to do something, to be engaged (Hoekstra, Chapagain, 2006).

Probably the most important legislative instrument for water is the Water Framework Directive of the European Union ${ }^{2}$. This directive will have to be implemented on an international scale across the European Union by the year 2027. The main objective is to achieve good water status by the year 2015 (Chave, 2001).

\footnotetext{
${ }^{2}$ Directive 2000/60/EC of the European Parliament and of the Council of 23 October 2000 establishing a framework for Community action in the field of water policy.
} 
On the basis of the Water Framework Member States have to consult with the public and stakeholders the awareness of water issues and their involvement in the decision making process (Ministry of Environment, 2004). The support and involvement of the public is a prerequisite for water protection and identification of problems and the most appropriate measures to address them, including the costs. Regulatory measures will not succeed without public support. European citizens play a vital role in the implementation of the Water Framework Directive and help governments find a balance between social, environmental and economic issues that need to be taken into account (European Commission, 2010).

The partial objective was to determine whether there is a difference in interest between those who live in the countryside and those who live in the city - whether people in the rural areas are more interested in water management than people in the city or whether awareness of water management is greater among people from cities and towns. As stated by many authors (Majerová et al., 2009; Perlín at al., 2012; Woods, 2011, etc.), the countryside is not easy to pinpoint, there is no uniform definition. In the Czech Republic a rural area is defined as a set of rural communities, the boundary is 2,000 people (there are many definitions). Rural municipalities represent $89.8 \%$ of all municipalities, but they administer territory, which constitutes $73.6 \%$ of the area of the country. But only a quarter of the population lives in rural areas $26.3 \%$ (Ministry of Regional Development, 2006). A rural area includes nature and rural settlements. The term, therefore, includes rural undeveloped area and small settlements villages. A rural area is characterized by a lower degree of socio-economic contact, smaller density of links between entities in rural areas (Perlín, 2007). A suburban area is made up of rural areas on the outskirts of big cities, which are mainly affected by suburbanization and currently a significant growth in its population is registered.

\section{Materials and methods}

In this study one of the methods of quantitative survey was used - a questionnaire survey which is one of the most common ways of collecting primary data. The questionnaire consists of questions to which respondents react or select options, if there is a choice of possible answers. Before creating the questionnaire, relevant literature was studied (Olecká, Ivanová, 2010; Řezanková, 2011; Walker, 2013). Preliminary research which led to the modification of the final questionnaire form including an introductory letter was carried out to remove all possible errors and uncertainties before the survey itself started. The preliminary research was conducted in April 2012 among randomly selected students of different classes and courses at Mendel University in Brno. The questionnaire was modified on the basis of this preliminary research and the final version was created.

The name of the pilot questionnaire was "Awareness of water management in the Czech Republic". Data collection and processing were completely anonymous. The questions were to discover interest of the population of the Czech Republic in water management. An effort was to choose questions that would be most representative. There was an attempt to formulate sentences in such a way that they are clear (without specialized terminology, foreign words and ambiguous expressions), short (short words and sentences) and easy to understand for all respondents.

The issue of water management is very extensive and it was not possible to include everything in this short questionnaire. Only a few areas of activities that address water management were selected. The questions were divided into three groups. Segmentation questions that describe the structure of a research sample (see below). Next was a group of questions that determine interest of people in water management. It was a simple, general question (Are you interested in the issue of water management in the Czech Republic? What issue of water management are you most interested in? Water management of the Czech Republic is of high level (in comparison with other European countries). Next was a group of questions that determine the level of information the population has in the area of water management. Here are questions related to the most important legislation - both Czech and European (Do you know that "big" amendment to the Water Act No. 254/2001 Coll. in 2010 entered into force? Do you know the European Union water framework directive 2000/60/EC establishing a framework for Community action in the field of water policy?). The reason for the creation of the survey was 
the fact that one of the main objectives of water policy of the European Union, on which water policy of the Czech Republic is based, is the need to increase public awareness of water issues and their involvement in the decision making process. Because of still more frequently occurring flood events, questions from this area of interest were also included (Have you ever experienced a flood? If you have experienced a flood, do you know what the acronym FL stands for?). The last two questions focused on the source of information on water management (Where did you get most information about water management? Do you know the Water Information System of the Czech Republic?). It is very important that people have access to information and also know where to look it up.

The information system WATER is a system of public administration: it is an interdepartmental project, which aims at unified presentation of information in the field of water under the auspices of the Czech central water authorities and provision of professional and public education, reliable and relevant information on water (for decision-making, education and general awareness), all of this can be found in one place (http://www.mzp.cz/cz/informacni_systemy).

The total number of questions in the pilot survey was 14 . Twelve of them were closed questions (respondents choose from the possible answers) and marked as required questions; two were open (expressed in the interviewee's own words) and marked as optional. Four final questions were used to identify gender, age and education. All questions were displayed simultaneously. The pilot questionnaire was in an electronic form and was published on the website www.vyplnto.cz, which is used to implement internet surveys. The authenticity of the questionnaire was secured by basic checks of IP addresses, from one computer the questionnaire could be filled out only once. The research work was carried out in the period from 26 April 2012 to 10 May 2012. Besides the vyplnto.cz website and partner sites, the questionnaire was published on the social networking site Facebook, on the document server of Mendel University, it was sent to students enrolled in the courses Landscape Ecology and to email addresses in the Information System of Mendel University and some other e-mail addresses. After the survey was closed, statistical analysis of identified primary data was made and graphs and tables were created. The results of the pilot survey can be found at: http://informovanost-v-oblasti-vodn.vyplnto.cz.

Another method employed was analysis of dependence. This method is used to verify the assumption that some responses are interdependent and some check is necessary. It is verification of hypotheses about the influence between two answers. Group selection (validity of statements in part B) was for particular purposes identified by the term antecedent, which means "I have directly experienced flooding". Those who did not experience flooding belonged to a group of non-antecedent. Respondents who indicated interest in water management formed a group called succedent. Those who were not interested in water management belonged to the group of non-succedent. All these four groups of respondents were entered into a four-field table, where antecedents and non-antecedents were set in rows, and succedents and non-succedents in columns. Each table cell showed the number of respondents belonging to the mentioned groups. At the top left (a) is the number of respondents who were interested in water management and also experienced flooding directly; at the top right (b) is the number of respondents who were interested in water management, but did not experience flooding directly; at the bottom left (c) is the number of respondents who were not interested in water management, but experienced flooding directly, and at the bottom right (d) are the respondents who were not interested in water management and they did not experience flooding directly. For each row and column total results, applicable to other calculations were created: deviation from the average: the percentage gives the percentage change in the probability of the antecedent compared to the overall probability of the succedent: $[a / a+b] /[(a+c) /(a+b+c+d)]$ and reliability implications: it gives what percentage of respondents is the antecedent. Ideally, the implication should be valid for at least $85.0 \%$ of cases; otherwise, there is no strong correlation between answers.

After the pilot survey was finished, it was decided that another questionnaire survey will be carried out. This additional survey was based on the results of the first survey - on the findings that people are most interested in drinking water supply and reducing consequences of extreme climatic events (flood, drought). This survey was called "Awareness of the Czech population of 
water management." The questionnaire consisted of nine closed questions (eight mandatory and one optional), where respondents chose the right option. The last four questions were their identification (gender, age, education and place of residence) and five questions assessed the respondent's interest in water management related to their normal, everyday life. There was an effort to select questions from an area which people encounter most often. As for the area of drinking water supply, the questions were related to charging for water and sewerage, quality of drinking water and quality of swimming water. In the area of reducing consequences of extreme climatic events (flood, drought) the following questions were asked: Was there any type of flood protection implemented in your place of residence? If so, what purpose does this protection fulfil? The results of the pilot survey showed that $64 \%$ of respondents have some experience with floods, so these two questions were selected. They were to show whether people are really interested in water management and especially in their place of residence. It was not important whether there was some type of flood protection implemented or not, but whether people are familiar with it.

To identify population a criterion of their place of residence was used. This was because one of the aims was to find out whether there are differences in the responses between the population living in the countryside (municipalities with less than 2,000 inhabitants), in towns (municipalities with over 2,000 inhabitants) and in suburban areas (rural communities within urban agglomerations, respectively narrowly defined urbanized area with more than 50,000 inhabitants).

The entire questionnaire was also anonymous and was conducted through direct interviews. The questionnaire was presented to randomly selected citizens of the Czech Republic in the streets of randomly selected cities (Brno, Ostrava, Šenov and Bohumín) during September 2012.

Using a questionnaire survey large amounts of data that had to be graded and assessed were obtained. The final questionnaire contained only closed questions, for evaluation of which the first degree of separation was used, i.e. a list of absolute and relative frequencies. The obtained data were tabulated in frequencies (Table 3) and graphs (Figures 5 - 19). For calculation and tables the following relation was used (Dufek, Stávková, 2004):

$$
p i=\frac{n i}{n}
$$

where: $\quad$ ni ....absolute frequency in the group

pi ....relative frequency in the group of [\%]

$n$...sample size

$i \ldots$ index $i=1,2, \ldots \ldots, k$

$k$...number of rows in the table

\section{Results and discussion}

\subsection{The results of the pilot survey}

\section{Basic information about respondents}

The pilot questionnaire had 14 questions and 230 respondents answered. The sample of respondents was composed of randomly chosen people living in the Czech Republic. The most important source of answers was the following servers: Unknown $(79.2 \%)$, facebook.com (12.6\%); google.cz (2.7\%); vyplnto.cz (1.9\%). 181 out of 230 respondents were women $(78.7 \%)$ and 49 men $(21.8 \%)$. Segmentation related to age, education and place of residence is shown in Tab. I. The survey revealed that the majority of respondents $(176,76.5 \%)$ were people aged from 15 to 25 , which is related to the fact that most respondents $(139,60.4 \%)$ received secondary education. 


\begin{tabular}{|l|l|r|r|}
\hline \multicolumn{2}{|l|}{} & Absolute frequency & Relative frequency (\%) \\
\hline Number of respondents & total & 230 & $100.00 \%$ \\
\hline & \multicolumn{2}{|c|}{} \\
\hline Gender & female & 181 & $79.00 \%$ \\
\hline & male & 49 & $21.00 \%$ \\
\hline Age & $15-25$ years & 176 & $77.00 \%$ \\
\hline & $26-35$ years & 47 & $20.00 \%$ \\
\hline & $36-49$ years & 6 & $2.60 \%$ \\
\hline & 50 years and over & 1 & $0.40 \%$ \\
\hline & & 2 \\
\hline Highest level of educating & primary school & 4 & $1.00 \%$ \\
\hline & secondary with no diploma & 139 & $2.00 \%$ \\
\hline & secondary with a diploma & 5 & $60.00 \%$ \\
\hline & higher professional education & 80 & $2.00 \%$ \\
\hline & university & $35.00 \%$ \\
\hline
\end{tabular}

Tab 1. Structure of a research sample. (Source: Author)

\subsection{Interest of the Czech population in the issues of water management}

The first part of the questionnaire focused on findings related to the interest in water management issues and consisted of the following three general questions:

Question 1. Are you interested in the issue of water management in the Czech Republic (an obligatory question, respondents had to choose between the answers "yes" and "no")? Some 152 (66.4\%) respondents answered "yes"; the remaining 78 (33.9\%) answered "no". This was the central question of the survey and the result shows that randomly selected inhabitants of the Czech Republic are quite interested in water management.

Question 2. What issues of water management are you most interested in (an obligatory question, respondents had to choose at least one of the available options (min. 1)? Seven possible answers were available. The respondents most frequently chose the answer "drinking water" - $134(58.3 \%)$, followed by "mitigating the effects of extreme weather events (floods and droughts) - $110(47.8 \%)$ and followed by "the protection of surface and groundwater" $74(32.3 \%)$. The smallest area of interest was "safety of waterworks" $15(6.5 \%)$. The overview of responses is shown in Figure 1.

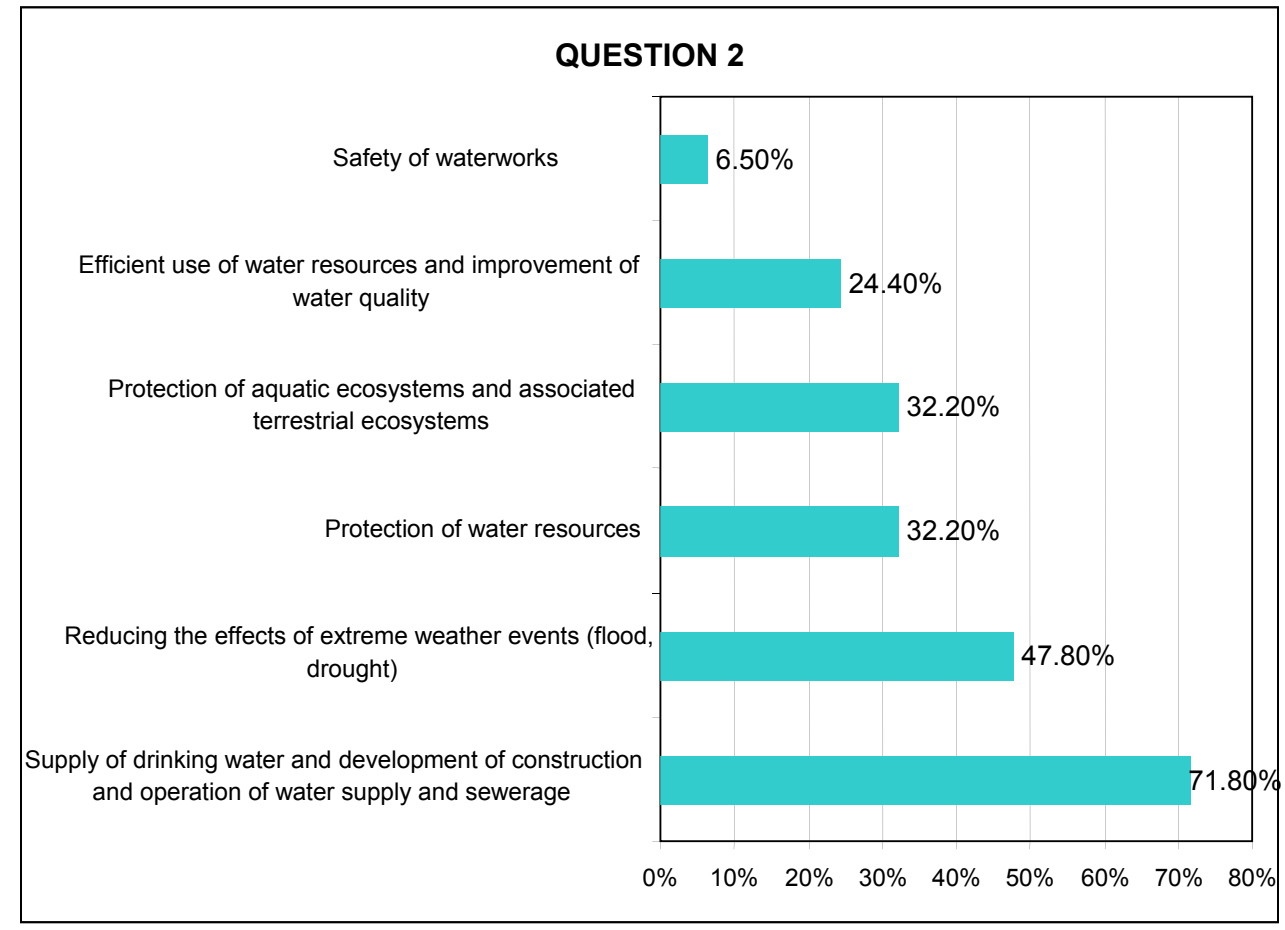

Fig 1. Which area of water management activities are people most interested in? (Source: Author) 
Question 3. Water management of the Czech Republic is of high level (in comparison with other European countries) (a compulsory question, the respondents had to decide between the responses "agree," "somewhat agree," "do not know", "somewhat disagree" and "disagree"). In this statement $95(41.0 \%)$ of respondents chose "agree" almost the same number $91(40.0 \%)$ chose "partially agree", $35(15.0 \%)$ of respondents chose the option "do not know", $8(4.0 \%)$ checked "partially disagree" and only $1(0.4 \%)$ checked "disagree".

\subsection{The awareness of the Czech population of water management}

This part of the questionnaire aimed to determine the level of public awareness of water management. Here is a selection of the most important questions regarding legislation, Czech and European. This legislation was the subject to the creation of this survey. One of the main objectives of water policy of the European Union, on which water policy of the Czech Republic is based, is the need to raise public awareness of water issues and their involvement in the decision-making process. For this reason questions relating to frequently occurring flood events were selected. The last two questions focused on the sources of information on water management. It is very important that people have an access to information and know where to look it up.

Question 4. Do you know that "big" amendment to the Water Act No. 254/2001 Coll. entered into force in 2010 (a compulsory question, respondents had to choose between the answers "yes" and "no")? A total of $184(80.0 \%)$ respondents answered "no", only $46(20.0 \%)$ said "yes".

Question 5. Have you ever experienced a flood (an obligatory question, respondents had to choose one of the suggested answers)? The overall results are shown in Figure 2. Five options were offered in the questionnaire. Most respondents $81(35.2 \%)$ chose the answer "I have not experienced a flood, only in the media (television, internet, newspapers, etc.)". The second most common response was "I have experienced a flood in my place of residence, but there was no damage to my property" - $50(21.7 \%)$ and the third most common response was "I have experienced a flood in my place of residence and my property was damaged" $37(16.9 \%)$ These results show that nearly $64.0 \%$ of respondents have experienced a flood in some way. The percentage of individual responses is shown in Figure 2.

\section{QUESTION 5}
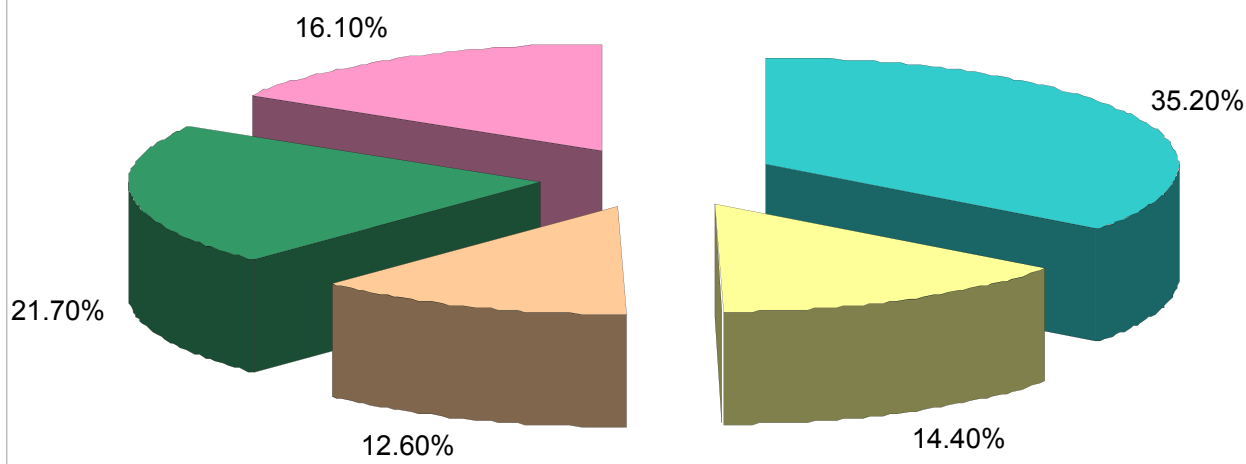

\footnotetext{
$\square$ I have not experienced a flood personally, only in the media (TV, internet, newspaper, etc.).

$\checkmark$ I have not experienced a flood personally, but a flood affected my relatives.

$\square \mathrm{I}$ have experienced a flood, but not in my place of residence (during a holiday, business trip, etc.).

I have experienced a flood in my place of residence, but there was no damage to my property.

$\square \mathrm{I}$ have experienced a flood in my place of residence and my property was damaged.
}

Fig 2. Have you ever experienced a flood? (Source: Autor) 
Question 6. If you have experienced floods, do you know what the acronym FL stands for (an optional question, the respondents could answer in their own words - an open question)? This optional question was answered by a total of 96 respondents. The correct answer was "flood level". Only 53 respondents (51.0\%) answered correctly.

Question 7. Where did you get most information about water management (a compulsory question, respondents had to choose at least one of the available responses (min. 1))? The responses are shown in Figure 3. Citizens of the Czech Republic received information about water management primarily from the Internet $172(74.8 \%)$, followed by television $137(59.6 \%)$, newspapers and the press 93 (40.4\%). These results could have been expected, mainly because the questionnaire was aimed at young people who spend part of their free time browsing the Internet.

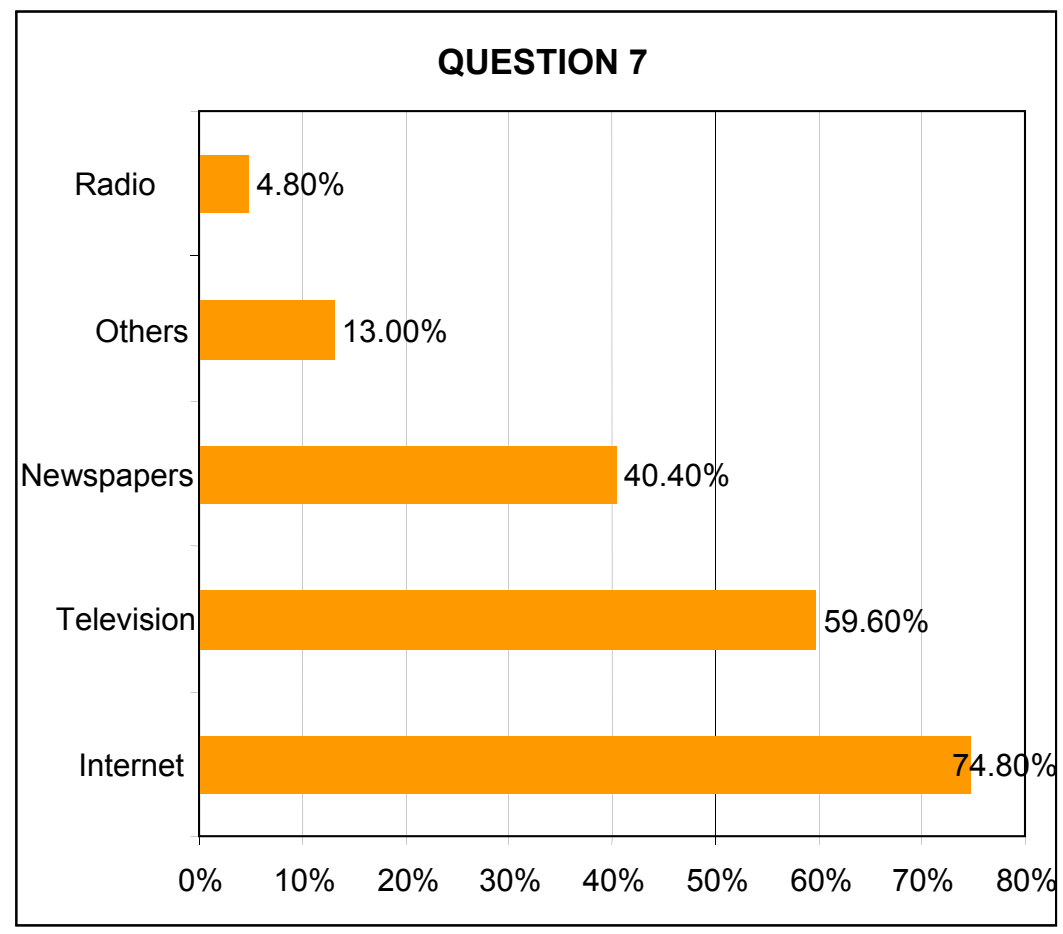

Fig 3. Where did you get most information about water management? (Source: Author)

Question 8. Do you know the Water Information System of the Czech Republic (a compulsory question, respondents had to choose between the answers "yes" and "no")? A total of $203(88.3 \%)$ responded "no", only 27 (11.7\%) said "yes."

Question 9. Do you know the European Union water framework directive 2000/60/EC establishing a framework for Community action in the field of water policy (a mandatory question, respondents had to choose between the answers "yes" and "no")? Like in the previous question, the prevailing answer was "no" - 181 (78.7\%); only 49 respondents (21.3\%) answered "yes".

Analysis of dependencies between "I am interested in the issue of water management in the Czech Republic" and "I have experienced a flood in my place of residence" showed dependence of succedents, 56 supported antecedents. The assumption that people who have directly experienced floods will be more interested in water management has been expressed by the fact that in recent years they have been increasingly exposed to flood situations and often experienced a threat to property or even human health. So effort to protect could increase their interest in the issue of water management. In the whole sample of respondents there is a probability of succedents only $66.1 \%$. The respondents who meet the antecedents got a probability of succedents of $64.4 \%$. The antecedent does not affect the succedent the answers in Part B do not affect the statement in Part A. A direct experience with floods did not influence people interested in the issue of water management in the Czech Republic. 
Reliability consequences are: for $64.4 \%$ respondents who meet the antecedent, is succedent validating. Strength implication is low. Reliability equivalence: $44.8 \%$ of respondents paid equivalence between the validity antecedent and succedent. Strength equivalence is low. Dependency is shown in Tab. 2.

\begin{tabular}{|c|c|c|c|}
\hline & Succedent & Non-succedent & Sum \\
\hline Antecedent & 56 & 31 & 87 \\
\hline Non-antecedent & 96 & 47 & 143 \\
\hline Sum & 152 & 78 & 230 \\
\hline
\end{tabular}

Tab 2. Table of four fields. (Source: Author)

\subsection{The results of a final survey}

This additional survey was created on the results of the first investigation. The questions were based on the findings that people are most interested in the area of drinking water supply and reducing the consequences of extreme climatic events (flood, drought). The aim was to select questions related to supply of drinking water which people deal with most often (charge for water and sewerage, quality of drinking water and swimming water, flood control). The questionnaire contained (among others) also questions as to where respondents live, because one of the objectives was to determine whether there are differences in responses between those living in rural areas (municipalities with up to 2,000 inhabitants), in villages (with less than 2,000 inhabitants) or in suburban areas (rural communities within urban agglomerations or narrowly defined urbanized area (with more than 50,000 inhabitants).

The questionnaire survey, which was carried out by direct interview, was attended by a total of 172 respondents. The structure of the sample is given in Tab. 3. A majority of respondents were women $(65.0 \%)$ (Women expressed greater willingness and understanding than men who were reserved and unpleasant), who had secondary education with a diploma (46.0\%) or a university degree $(42.0 \%)$. The age of the respondents was evenly distributed in all four categories. Distribution of respondents by place of residence is as follows: $51 \%$ live in urban areas, $35 \%$ live in rural areas and $14 \%$ live in suburban areas.

Question 1. Do you know the charge for water and sewerage that you pay (a compulsory question, the respondents had to decide between the answers "yes" or "no")? $70.0 \%$ of respondents answered yes (Figure 4 ).

Question 2. Was there any type of flood protection implemented in your place of residence (a compulsory question, the respondents had the opportunity to choose the answer "yes", "no" or "I don't know")? Since the results of the pilot survey showed that $64 \%$ of respondents have experienced floods, this question, which was related to the previous one, was selected to show that the residents are informed about what is happening around them in water management. Figure 5 shows that a total of $82 \%$ of respondents know that in their place of residence is or is not some type of flood protection ( $62 \%$ of respondents think that the flood protection is likely to fulfil its purpose, $23 \%$ of respondents think that the flood protection fulfils its purpose). Only $18 \%$ of respondents do not know. These results show good awareness of the population of water management in their everyday lives.

Question 4 Are you interested in the quality of drinking water from the tap (an obligatory question, respondents had the opportunity to choose the answer "yes," "probably yes," "rather no" or "no")? People have interest in the quality of tap water. $76.0 \%$ of respondents answered "yes" and 14.0\% "probably yes", only 5.0\% "no" and 5.0\% "rather no" (Figure 7). 


\begin{tabular}{|c|c|c|c|}
\hline & & $\begin{array}{l}\text { Absolute } \\
\text { frequency }\end{array}$ & $\begin{array}{l}\text { Relative frequency } \\
\text { (\%) }\end{array}$ \\
\hline Total number of respondents & & 172 & $100 \%$ \\
\hline \multirow[t]{2}{*}{ Gender } & female & 112 & $65 \%$ \\
\hline & male & 60 & $35 \%$ \\
\hline \multirow[t]{4}{*}{ Age } & to 25 years & 48 & $28 \%$ \\
\hline & $25-35$ years & 40 & $23 \%$ \\
\hline & $36-50$ years & 32 & $19 \%$ \\
\hline & 50 years and more & 52 & $30 \%$ \\
\hline \multirow[t]{5}{*}{$\begin{array}{c}\text { The highest level of received } \\
\text { education }\end{array}$} & primary school & 4 & $2 \%$ \\
\hline & $\begin{array}{l}\text { secondary with no } \\
\text { diploma }\end{array}$ & 8 & $5 \%$ \\
\hline & $\begin{array}{l}\text { secondary with a } \\
\text { diploma }\end{array}$ & 80 & $46 \%$ \\
\hline & $\begin{array}{l}\text { higher professional } \\
\text { education }\end{array}$ & 8 & $5 \%$ \\
\hline & university & 72 & $42 \%$ \\
\hline \multirow[t]{3}{*}{ Place of residence } & urban space & 88 & $51 \%$ \\
\hline & suburban space & 24 & $14 \%$ \\
\hline & rural space & 60 & $35 \%$ \\
\hline
\end{tabular}

Tab 3. Structures of research group. (Source: Author)

Question 5 Are you interested in the quality of swimming water (swimming pools, dams, lakes, etc.) (a compulsory question, the respondents had the opportunity to choose answers "yes," "probably yes," "rather no" or "no")? People are also interested in the quality of bath water. $44.0 \%$ responded that they are interested, $35.0 \%$ said "probably yes", and only $5.0 \%$ showed a complete lack of interest (Figure 8).

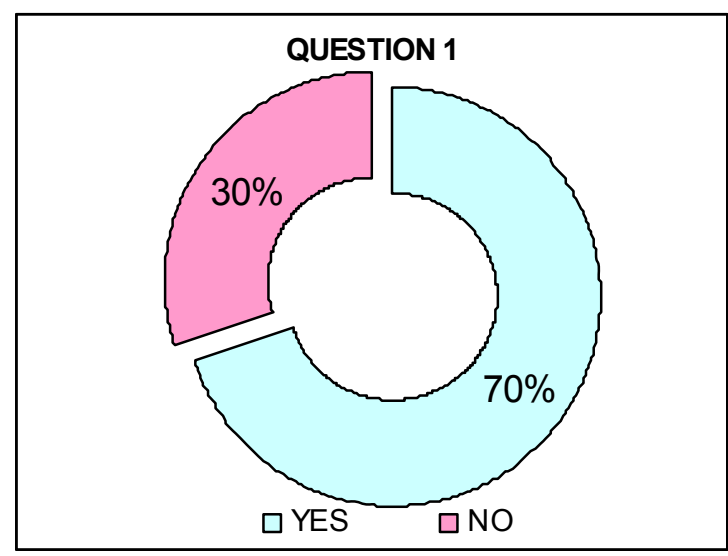

Fig 4. Do you know the charge for water and sewerage that you pay?

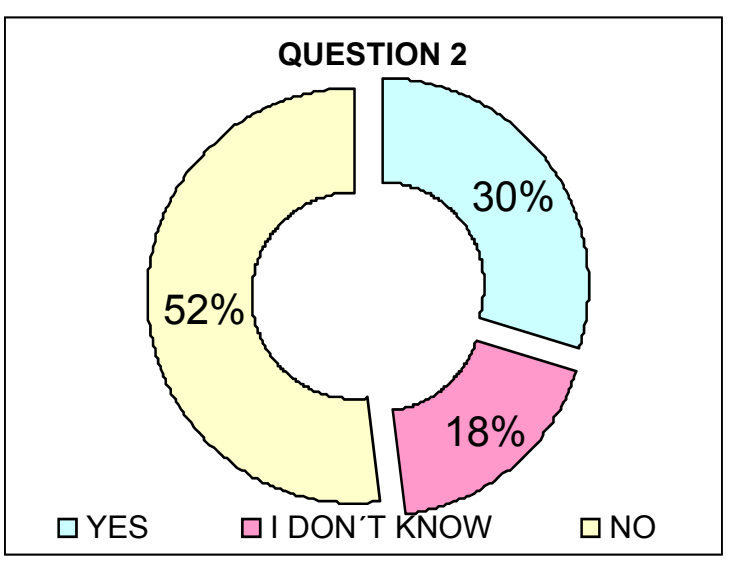

Fig 5. Was there any type of flood protection implemented in your place of residence? 


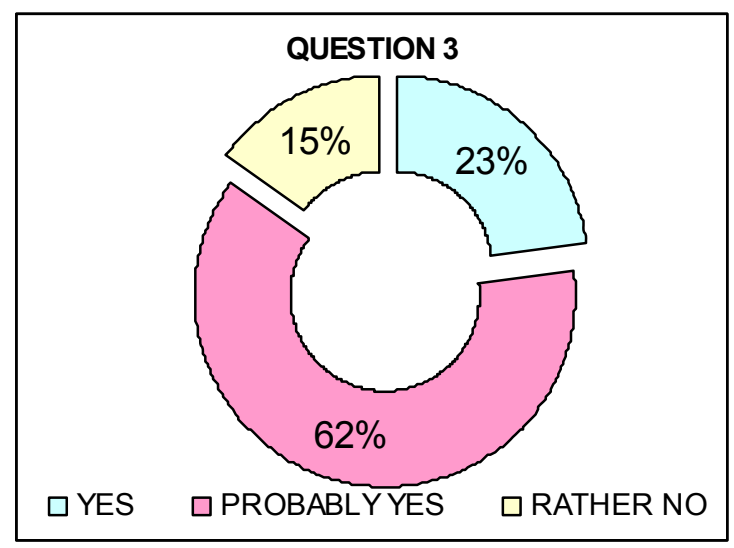

Fig 6. If so, does this protection fulfil its purpose?

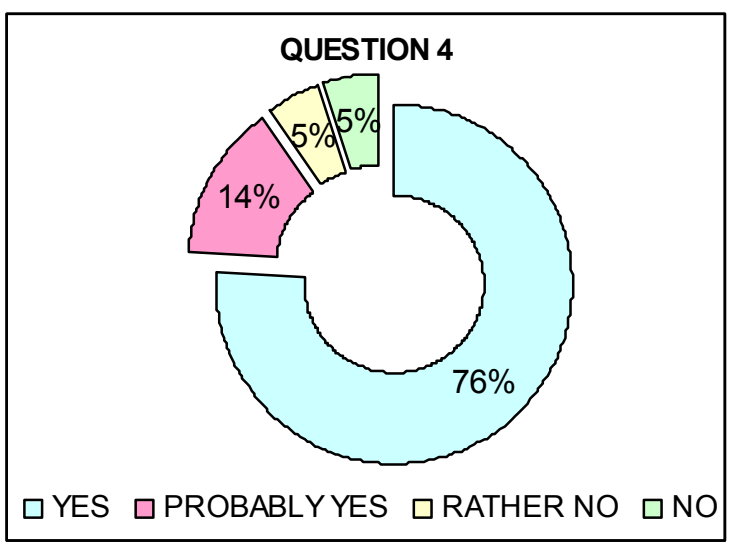

Fig 7. Are you interested in the quality of tap water?

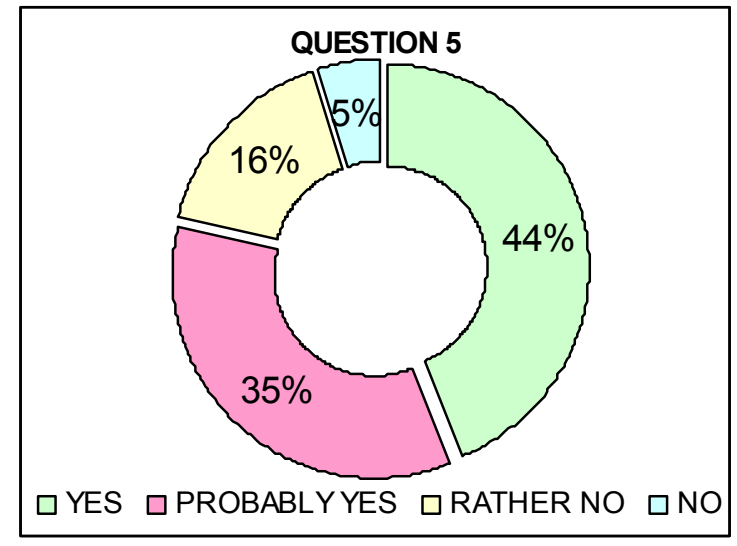

Fig 8. Are you interested in the quality of bath water (swimming pools, etc.)?

\subsection{Comparison of answers of the respondents living in urban and rural areas}

As we can see in Figure 9, the distribution of respondents living in urban and rural (suburban + rural areas combined) areas is almost the same (ca 50\%).

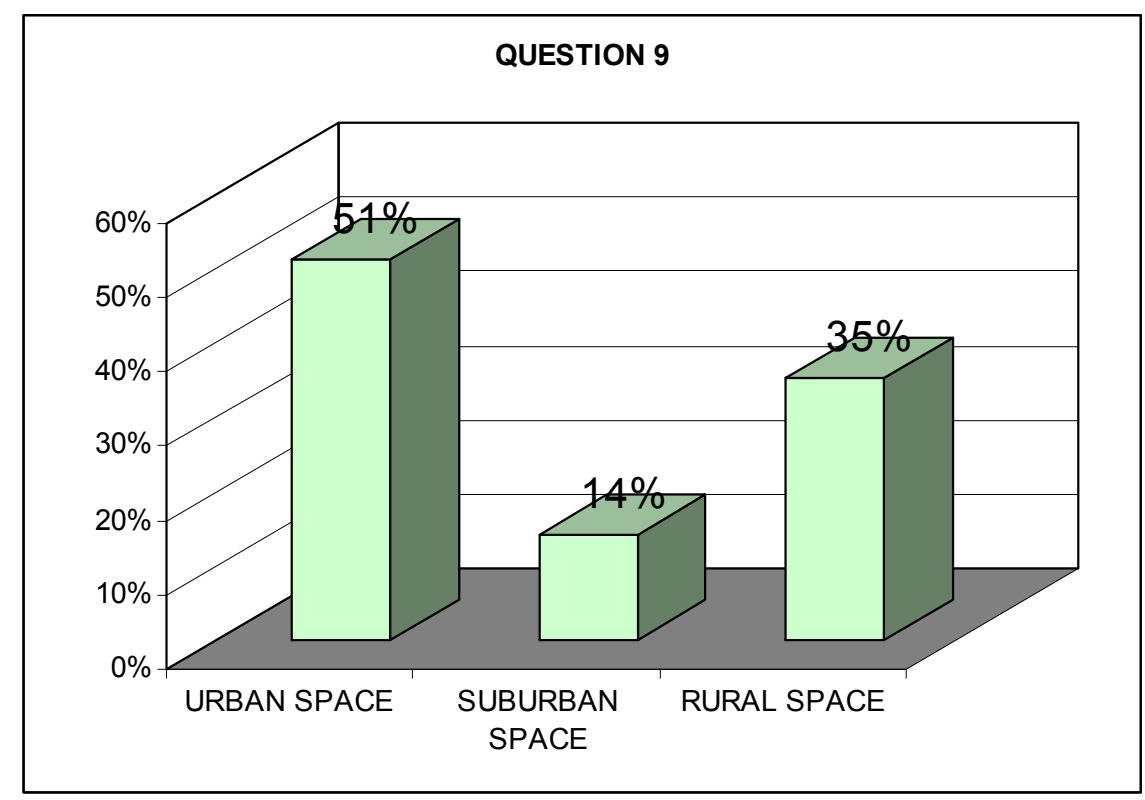

Fig 9. Where is your place of residence? (Source: Author) 
In Question 1, when asked if they knew the approximate cost of water and sewage charges paid, there were no differences between people living in urban, suburban or rural areas. The prevailing answer was "yes."

In Question 2, when asked if some type of flood protection measures was implemented in their place of residence similar results as in the previous question were obtained. In urban and rural areas the predominant answer was "no." In the suburban area, the result was different. The dominant answer was "yes."

Question 3, which followed question 2 (if the respondent answered "yes"), reaffirmed almost identical results in all residential areas, without major differences a prevailed answer is "probably yes."

In Question 4 as to whether the respondents are interested in the quality of drinking water from the tap there were no differences in the results. The majority of respondents answered "yes." Only in rural areas, there was no response "rather not" and "no."

In question 5, which examined whether people are interested in the quality of bath water, there were no significant differences in responses between individual areas and the prevailing answers were "yes" and "probably yes". In rural areas, only now there is no answer "no."

The sample population representing urban space consisted mainly of university - educated women between the age of 50 and then to 25 years. The sample population representing suburban area consisted mainly of men with secondary education aged 36-50. In the sample population representing rural areas dominant were women with secondary education (with a diploma) under 25.

The results of the survey show that there were no significant differences in confirmed awareness of water management among the Czech population, who lives in urban, suburban or rural areas (Figures 10-17).

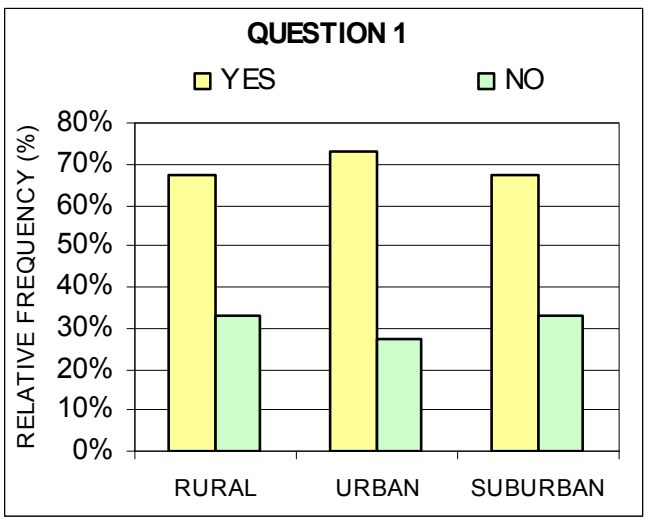

Fig 10. Do you know the charge for water and sewerage that you pay?

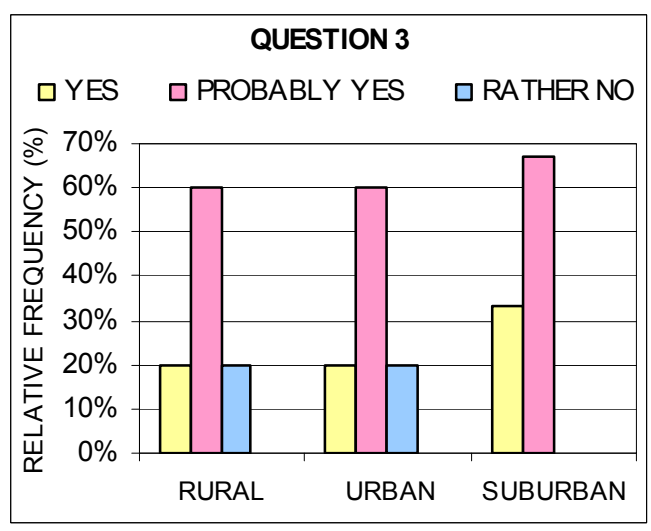

Graph 12. If so, does this protection fulfil its purpose?

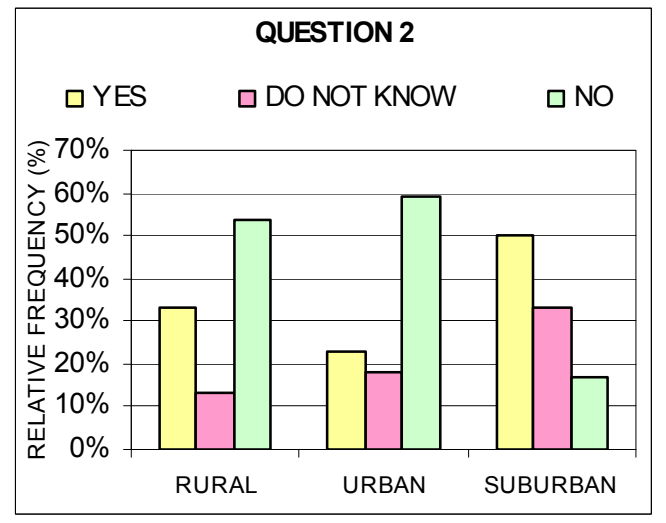

Graph 11. Was there any type of flood protection implemented in your place of residence?

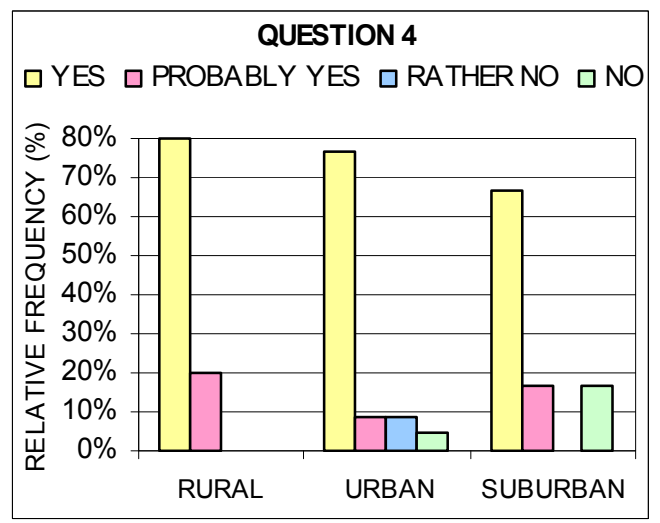

Graph 13. Are you interested in the quality of drinking water from the tap? 


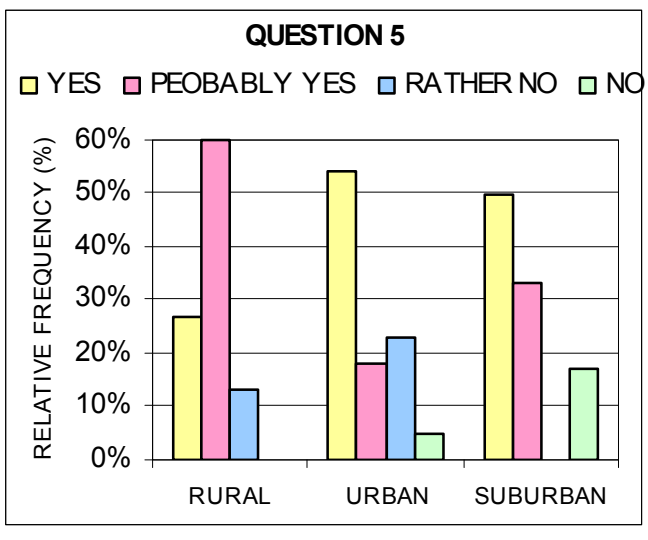

Fig 14. Are you interested in the quality of bath waters (swimming pools, etc.)?

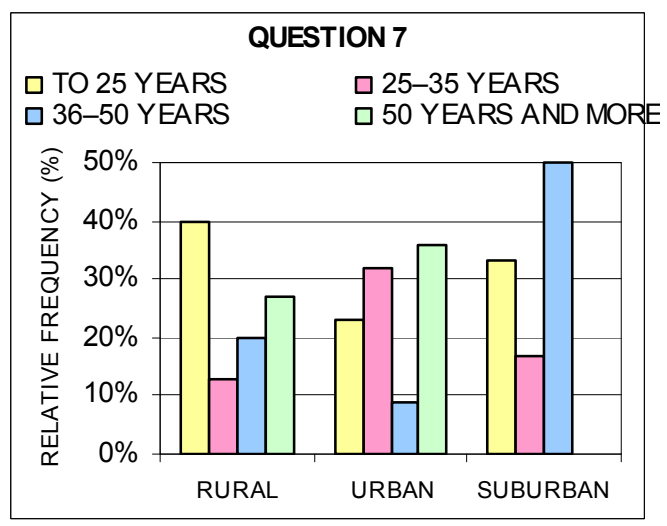

Fig 16. How old are you?

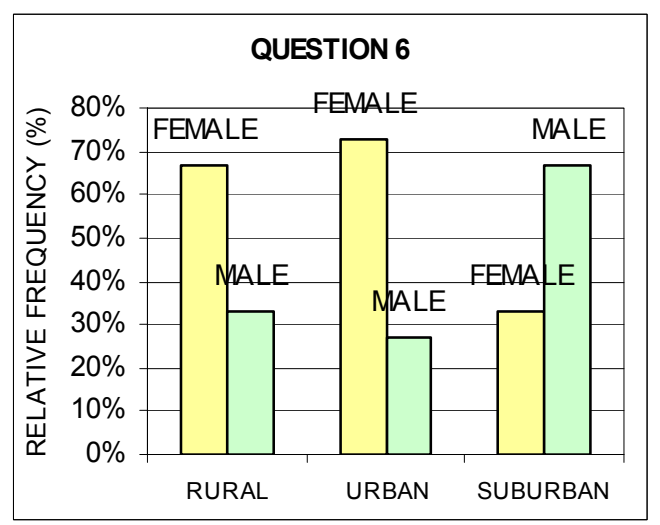

Fig 15. What is your gender?

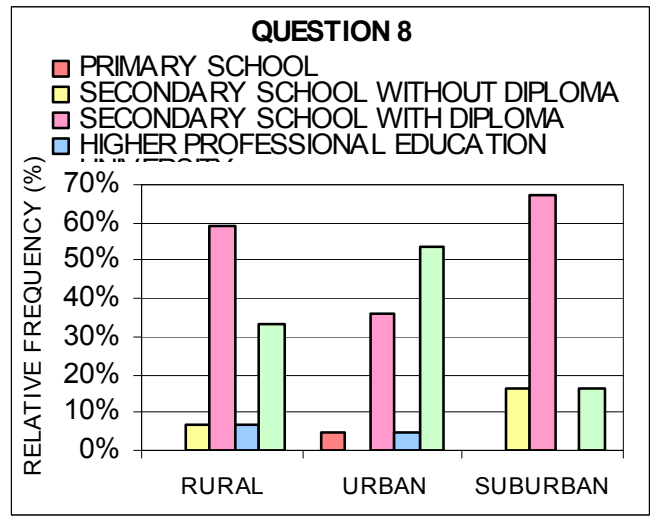

Fig 17. What is the highest level of your education?

\section{Conclusions}

The importance and necessity of effective water management of each state is irrefutable. The aim of this article was to determine whether residents of the Czech Republic have interest in water management and whether they are well-informed. The main research method was a questionnaire survey, which was carried out by a total of 172 respondents $(65.0 \%$ of women and $35.0 \%$ of men). This questionnaire was preceded by a pilot survey, which was conducted by a total of 230 respondents $(79.0 \%$ of women and $21.0 \%$ of men).

The pilot survey was aimed at a young, educated generation at the age under $25(77.0 \%)$. A vast majority had secondary education with a diploma $(60.0 \%)$. The overall assessment indicates that the inhabitants of the Czech Republic have interest in the issue of water management $(66.0 \%)$. As for water management issue they were mostly interested in drinking water; in how to mitigate the effects of extreme weather events (floods, drought), and how to protect surface and ground waters, aquatic ecosystems and directly dependent terrestrial ecosystems. The rest of the people were interested in safety of dams. With the statement "Water management is at high level in the Czech Republic" only $3.5 \%$ agreed, most respondents answered "I do not know" (41.3\%) and "I agree" (39.6\%). Although residents of the Czech Republic expressed interest in water management, their awareness of it is quite poor. A total of $78.7 \%$ said they did not know of the European Union Water Framework Directive 2000/60/EC, 88.3\% do not know about the Water Information System of the Czech Republic, $80.0 \%$ do not know that in 2010 "big" amendment to the water law came into effect. The assumption that people who have personally experienced floods will be more interested in water management was not confirmed. In the whole sample of respondents succedent is $66.1 \%$, among respondents meeting the antecedent probability succedent is $64.4 \%$. Antecedent does not affect succedent - answers in Part B do not affect statements in Part A, i.e., direct 
experience with floods did not affect interest of the Czech population in the issue of water management.

After finishing the pilot survey, it was decided that another questionnaire survey would be carried out. This additional survey was based on the results of the first investigation. The choice of questions was based on the findings that people are most interested in the area of drinking water supply and mitigating the consequences of extreme climatic events (flood, drought).

The results of the final survey, which was conducted through direct interviews, show that people are informed and have great interest in water management, regardless of their age or level of education. $70.0 \%$ of respondents know the approximate cost of water and sewage rates paid. $76.0 \%$ of respondents have interest and $15.0 \%$ are more interested in the quality of drinking water from the tap. $44.0 \%$ are interested and another $35.0 \%$ are more interested in the quality of bath water (water tanks, swimming pools, etc.).

A hypothesis was formulated that there are no differences in the awareness of water management between people of the Czech Republic living in the urban, suburban and rural areas. The results of the questionnaire showed no difference in the responses of respondents on the basis of their place of residence. It can, therefore, be assumed that the place of residence does not have any influence on interest in the issue of water management. Water affects lives of all of us but it does not matter whether we live in the city or in the countryside.

Yet, the area of water management activities is very extensive and a short survey cannot include all results relating to residents of the Czech Republic and their interest in water management. People recognize the need for proper water management and the necessity of water for our daily lives. Clean water is no longer taken for granted; it is a very valuable asset, which is steadily disappearing. This decrease is caused by poor, wasteful management of water resources on the planet and also climate change.

Great interest is in what most significantly affects people's lives. More and more frequently occurring floods, affecting more and more people lead to more people being interested in this area. They want to protect their own lives and property $(64 \%$ of respondents have experienced a flood and $82 \%$ of respondents know that in their place of residence there is or is not some type of flood protection). Also, people are most interested in drinking water supply. People are mainly interested in the charges for water and sewage and the quality of drinking water. This may be due to the worsening economic situation of the country. People are concerned about prices, because prices are still rising.

The entire survey only confirmed the assumption that the inhabitants of the Czech Republic have interest in water management. This fact is related to improving the quality of life and increasing awareness of people. We are not indifferent to the quality of water we drink and water in which we swim in lakes. Furthermore, people are influenced by the current state and the trends of climate change, which are manifested by extreme weather events. Many people have first-hand experience with the destructive power of floods. In connection with these events interest in activities in the field of water management has increased. Residents are interested in how to protect and mitigate the effects of extreme weather events.

\section{Acknowledgment}

I would like to thank the reviewers of this article for their time to help improve this paper and for their valuable advice and comments. Finally, I would like to thank PhDr. Ivana Tulajová for her time to help with language rules. 
[1] Bates, B., Kundzewicz, Z. W., Wu, S. \& Palutikof, J., eds. (2008). Climate change and water. [Technical paper of the intergovernmental panel on climate change]. Geneva: IPCC Secretariat.

[2] Biswas, A. K. (2004). Integrated water resources management: a reassessment. Water International 29(2), 248-256. Doi: 10.1080/02508060408691775.

[3] Dufek, J. \& Stávková, J. (2004). Marketing research. Brno: Mendel University in Brno.

[4] Hoekstra, A. Y., Chapagain, A. K. (2006). Water footprints of nations: Water use by people as a function of their consumption pattern. Water Resources Management 21(1), 35-48. Doi: 10.1007/s11269-006-9039-x.

[5] Chave, P. (2001). The EU water framework directive: an introduction. London: IWA publishing.

[6] Implementace rámcové směrnice EU pro vodní politiku v České republice (2004). Praha : Ministerstvo životního prostředí ČR.

[7] Kniezková T. (2012). Informovanost v oblasti vodního hospodářství ČR (research results) [online]. Available at: http://informovanost-v-oblasti-vodn.vyplnto.cz.

[8] Li, Y. P., Huang, G. H., Nie, S. I. \& Chen, X. (2011). A robust modelling approach for regional water management under multiple uncertainties. Agricultural Water Management, 98(10), 1577-1588 Doi: 10.1016/j.agwat.2011.05.008.

[9] Majerová, V. et al. (2009). Český venkov 2008. Proměny venkova. Praha: Česká zemědělská univerzita.

[10] Strategie regionálnho rozvoje České republiky (2006). Praha: Ministerstvo pro místní rozvoj ČR.

[11] Ministerstvo životního prostředí ČR (2012). Voda. Informační systémy [online][cit. 2013-0205]. Available at http://www.mzp.cz/cz/informacni_systemy.

[12] Oki, T., Kanae, S. (2006). Global hydrological cycles and world water resources. Science 313(5790), 1068-1072 Doi: 10.1126/science.1128845.

[13] Olecká, I., Ivanová, K. (2010). Metodologie vědecko-výzkumné činnosti. Olomouc: Moravská vysoká škola Olomouc.

[14] Perlín, R. (2008). Venkov, typologie venkovského prostoru. Praha: Ministerstvo vnitra ČR.

[15] Perlín, R., Kučerová, S. \& Kučera, Z. (2010): Typologie venkovského prostoru Česka. Geografie, Sborník ČGS 115(2), 161-187.

[16] Plecháč, V. (1999). Vodní hospodářství na území České republiky, jeho vývoj a možné perspektivy. Praha: EVAN.

[17] Řezanková H. (2011). Analýza dat z dotazníkových šetření. Praha: Professional publishing.

[18] Strategie regionálního rozvoje České republiky (2006). Praha: Ministerstvo pro místní rozvoj ČR.

[19] Walker I. (2013): Výzkumné metody a statistika. Praha: Grada.

[20] Woods, M. (2011), Rural. London; New York: Routledge. 